\title{
FLOW CYTOMETRIC ANALYSIS OF NUCLEAR DNA BETWEEN OKRA LANDRACES (ABELMOSCHUS ESCULENTUS L.)
}

\author{
Naser M. Salameh \\ Department of Plant Production, Faculty of Agriculture, Mutah University, Al Karak, Jordan
}

Received 2013-12-25; Revised 2014-02-11; Accepted 2014-02-13

\begin{abstract}
Okra Abelmoschus esculentus L. (Moench), is an economically important vegetable crop grown in tropical and sub-tropical as well as Mediterranean countries. The genome size of the Abelmoschus genus species is still rare. Ploidy determinations have traditionally been done by counting chromosomes of stained root tips, but this method is laborious and often difficult with species which have small chromosomes and high ploidy levels and can lead to misclassified. Flow cytometry has been widely used in various aspects of plant research, such as the determination of the DNA nuclear content. Nuclear DNA size of fifteen okra genotype was measured using flow cytometry. The data showed variation between Turkish genotype and Jordanian

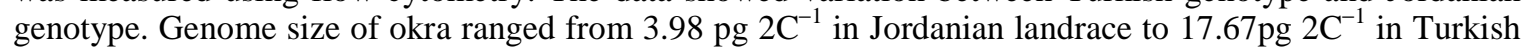
landrace. The 2C genome size in Mbp ranged from 3897-17321 among Abelmoschus esculentus genotypes. Further studies is recommended to accurate chromosome count to be linked with the genome size.
\end{abstract}

Keywords: Okra, Genome Size, Flow Cytometry, Relative DNA Content

\section{INTRODUCTION}

Okra Abelmoschus esculentus L. (Moench), is an economically important vegetable crop grown in tropical and sub-tropical as well as Mediterranean countries (Duzyaman and Vural, 2003). This crop is suitable for cultivation as a garden crop as well as on large commercial farms. Okra is cultivated for its fibrous fruits or pods containing round, white seeds. The fruits are harvested when immature and eaten as a vegetable. Okra fruit can be cooked in a variety of ways. Despite being a minor crop okra has gained considerable interest as an alternative to traditional vegetables in many countries throughout the world. This vegetable provides an important input of vitamins and mineral salts, including calcium; which are often lacking in diet of developing countries (Omonhinmin and Osawaru, 1991). Okra seeds have also gained much interest as a new oil and protein source (Duzyaman, 1997).

The origin of okra remains unclear, but center of genetic diversity include West Africa, India and Southern Asia (Hamon and Van Sloten, 1998). There are significant variations in the chromosome numbers and ploidy levels of different species in the genus Abelmoschus (Charrier, 1984). The chromosome number and ploidy levels of different species are given in Table $\mathbf{1 .}$

Jordanian landraces have diverse characters (Salameh and Kasrawi, 2007). Its red fruit color is dominant over green and this trait is controlled by two independent genes. The length of fruits, their diameter and number of ridges are quantitatively inherited traits (Salameh and Kasrawi, 2011). The difference in gene numbers controlling these characters may be due to the presence or absence of genes or the presence or absence of entire chromosomes. Mahadeen (2014) showed that there is an increase in okra growing in Jordan.

However very little information is available about cytogenetics and reproductive biology of this very important vegetable crop.

As the accurate amount of nuclear DNA content is extremely important to understand the hereditary constituent of an organism, flow cytometry, originally developed for medical studies, is an easy, rapid, accurate and convenient tool for estimating plant genome size, ploidy level, assessing DNA content and analyzing the cell cycle (Greilhuber, 1998; Winkelmann et al., 1998). 
Table 1. Variation of chromosome number in okra (Abelmoschus esculentus L.) (Charrier, 1984)

\begin{tabular}{lll}
\hline Species & Number (2n) & Authers \\
\hline (Abelmoschus esculentus L.) & \pm 66 & Ford (1938) \\
& 72 & Kamalova (1977) \\
& 108 & Datta and Naug (1968) \\
& 118 & Krenke (In: Tischler, 1937) \\
& 120 & Purewal and Randhawa (1947) \\
& 122 & Krenke (In: Tischler, 1937) \\
& 124 & Kuwada (1961; 1966) \\
& $126-134$ & Chizaki (1934) \\
& 130 & Skovsted (1935); Gadwal et al. (1968) \\
& $131-143$ & Siemonsma (1981) \\
& \pm 132 & Medvedeva (1936); Roy and Jha (1958) \\
& 144 & Breslavetz et al. (1934) \\
\hline
\end{tabular}

Voluminous information on the nuclear DNA contents in plants is being published by Bennett et al. (2000) and Hanson et al. (2001).

In addition to determining the nuclear DNA content, flow cytometry in higher plants is used for studying plant protoplast (protoplast size, cell wall synthesis, chlorophyll content, alkaloid content, RNA content, protein content, protoplast-microbe interaction, sorting of protoplast fusion products) and chromosomes (chromosome size, centromeric index, sorting of large quantities of chromosomes of single type for gene isolation and mapping) (Lucretti et al., 1999).

Flow cytometry allows reliable and rapid estimation of nuclear DNA content. This method finds numerous applications in plant taxonomy and breeding. The prominent applications have been ploidy level determination, analysis of nuclear DNA content and genome size estimation. Moreover flow cytometry has become increasingly popular and has been used for genome analysis in a variety of species (Palomino et al., 2003).

Genome size of different animals e.g Dairy goat (Fletcher et al., 2013) as well as different, plants has been estimated by flow cytometry like Pinus (O'Brien et al., 1996), Lemon (Iannelli et al., 1998), Arachis hypogeal (Temsch and Greilhuber, 2000), Musa (Roux et al., 2003), Atriplex halimus (Walker et al., 2005), Consolea (Negron-Ortiz, 2007), Vicia faba (Kovarova et al., 2007) Cactus (Lema-Ruminska, 2011), Coffea (Clarindo et al., 2012), Calendula species (Nora et al., 2013), Eryngium (Tavares et al., 2013), Lathyrus (Ochatt et al., 2013) and Phragmites austalis (Nakagawa et al., 2013).

However, regardless of the increasing importance of nuclear DNA content, to our knowledge, there are no genome size estimations available for Abelmoschus available. Therefore, the present study is the first attempt at defining the size of the genome of okra by measuring the nuclear DNA content using Flow Cytometry.

\section{MATERIALS AND METHODS}

\subsection{Plant Materials}

Different landraces have been collected from different parts of Jordan in addition to some landraces from the neighboring countries (Table 2).

\subsection{Flow Cytometry}

Preliminary attempts to use leaves of okra plants did not produce any results, presumably due to abundant mucilage and acidity of the tissue. Subsequently, a suspension of intact nuclei of landrace root tissue was analyzed by flow cytometry using the kit with Cystain UV precise $\mathrm{P}$ kit from Partec. Three individuals per accession were chopped in $400 \mu \mathrm{L}$ extraction buffer, then after addition of $1600 \mu \mathrm{L}$ staining buffer the tissues were mixed well. The suspension was filtered with Celltrics-filter $(\sim 50 \mu \mathrm{m})$ in a cuvette. The DNA content of each sample was measured using the Partec Cell Analyzer II. As a quality control, nuclear DNA content estimates were only considered when the coefficient of variation of $\mathrm{G}_{0} / \mathrm{G}_{1}$ peaks $\left(\mathrm{CV}_{\text {peaks }}\right)$ was below $5 \%$. Samples with higher $\mathrm{CV}_{\text {peaks }}$ values were discarded and new sample was prepared. Maize KYS nuclei were used as the internal reference standard. Relative DNA content of individual plant was expressed using a DNA Index (DI) calculated according to the formula:

Sample 2C DNA content $=$

$\frac{\text { Sample } G_{1} \text { peak mean }}{\text { Standard } G_{1} \text { peak mean }} \times$ standard $2 \mathrm{C}$ DNA content $(p g$ DNA) 


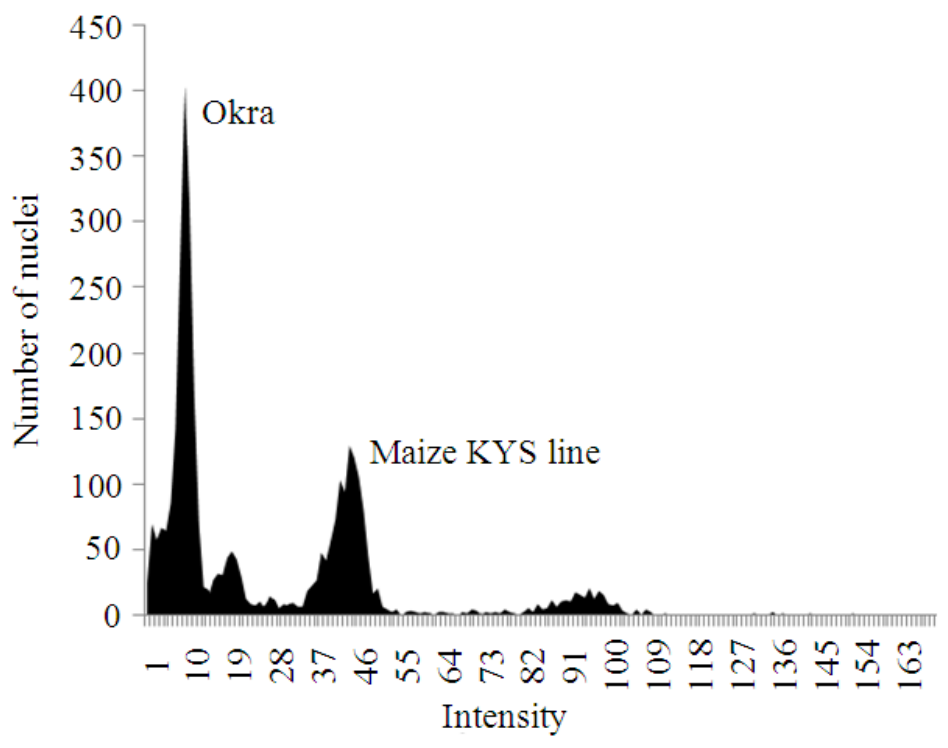

Fig. 1. Flow cytometric histogram of relative fluorescence intensity obtained after simultaneous analyses of nuclei isolated from roots of Abelmoschus esculentus

Table 2. Nuclear DNA content estimations in Abelmoschus esculentus

\begin{tabular}{llll}
\hline Landrace & Origin & 2C value (pg), FC & No. of Mbp \\
\hline Okra 12 & Turkey & 17.67 & 17321 \\
Okra 19 & Egypt & 4.82 & 4720 \\
Okra 20 & Egypt & 5.66 & 5543 \\
Okra 21 & Jordan & 4.46 & 4374 \\
Okra 22 & Jordan & 5.57 & 5456 \\
Okra 23 & Jordan & 3.98 & 3897 \\
Okra 24 & Jordan & 5.04 & 4936 \\
Okra 26 & Jordan & 4.51 & 4417 \\
Okra 27 & Jordan & 5.83 & 5716 \\
Okra 28 & Jordan & 4.55 & 4460 \\
Okra 29 & Jordan & 6.67 & 6539 \\
Okra 30 & Jordan & 6.62 & 6149 \\
Okra 34 & Jordan & 4.55 & 4460 \\
Okra 35 & Jordan & 5.08 & 4980 \\
Okra 38 & Jordan & 4.73 & 4633 \\
\hline
\end{tabular}

The DNA content (pg) was converted to megabase pairs of nucleotides (Mbp) using the relationship 1pg = $978 \mathrm{Mbp}$ (Dolezel et al., 2003).

\section{RESULTS}

Flow Cytometry histograms presented two dominant peaks, corresponding to the $\mathrm{G}_{0} / \mathrm{G}_{1}$ nuclei of the sample and the primary reference standard. The stained nuclei generated histograms of the relative DNA contents of sample and comparative primary standard as shown in Fig. 1. The 2C nuclear DNA content of Abelmoschus

esculentus was determined, for the first time, using flow cytometry (Table 2). Genome size of okra ranged from

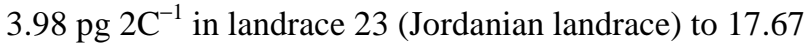
pg $2 \mathrm{C}^{-1}$ in landrace12 (Turkish landrace). The $2 \mathrm{C}$ genome size in Mbp ranged from 3897-17321 among Abelmoschus esculentus genotypes corresponding to $4.4 \%$ of variation between them.

\section{DISCUSSION}

The amount of DNA per chromosome set is known to be a fairly constant characteristic of a species. Therefore, in addition to the number of chromosomes, which are since long regarded as an important tool for delimiting species, in the past two decades an increasing interest on genome size studies and its significance has been observed, with many studies aiming at using genome size as a taxonomic marker (Kron et al., 2007). Despite this increase, the complex genus Abelmoschus has been completely neglected in the literature and the genome size values presented in this study are the first estimates for the genus.

The relative nuclear DNA content was estimated in fifteen genotypes of Abelmoschus esculentus. Ploidy level has traditionally been determined based on chromosome counts. Recent studies have estimated ploidy level based on assessments of nuclear DNA content using flow cytometry (Marhold et al., 2010). Flow cytometry is a relatively convenient and rapid method compared with chromosome counts (Suda et al., 2007). 
There was a variation in nuclear DNA content among Abelmoschus esculentus genotypes. Differences in genome size are known to be largely caused by different amounts of noncoding repetitive DNA, to which transposable elements, satellite DNA, introns and pseudogenes can contribute (Bennett and Leitch, 2005).

The variation in nuclear DNA content could be shown between the Turkish genotype in one side and the other genotypes in the other side. This variation has been in accordance with (Rayburn and Auger, 1990) who found a significant positive correlation between genome size of corn and altitude, suggesting that corn follows the trend of increasing DNA content with increasing altitude.

Kron et al. (2007) revealed that the individuals of Eryngium duriaei from higher altitudes presented a significantly higher genome size than those belonging to populations from lower altitudes.

\section{CONCLUSION}

In conclusion, this work contributed with important basic scientific knowledge on genome size in the cytologically complex genus Abelmoschus. Indeed further research should be conducted to find the accurate chromosome count and to link the chromosome number with the nuclear DNA content as a first step for starting breeding program of okra

\section{ACKNOWLEDGMENT}

The researcher wishes to thank Professor Gerd Weber, Department of Plant Breeding and Biotechnology (University of Hohenheim, Germany) for making it possible for the research to be made, Dorothee Stöckle for the assistance provided with Cytometric analysis, Dr Duzyaman for providing the Turkish landrace and the DFG (deutsche forschungsgemeinschaft) for their fund.

\section{REFERENCES}

Bennett, M.D. and I.J. Leitch, 2005. Genome Size Evolution in Plants. In: The Evolution of the Genome, Gregory, T.R., (Ed.), Elsevier Academic Press, Burlington, MA., ISBN-10: 0080470521, pp: 89-162.

Bennett, M.D., P. Bhandol and I.J. Leitch, 2000. Nuclear DNA amounts in angiosperms and their modern uses -807 new estimates. Ann. Bot., 86: 859-909. DOI: 10.1006/anbo.2000.1253
Breslavetz, L., G. Medwedewa and M. Magitt, 1934. Zytologische untersuchungen der bastpflanzen. Zeits. Zucht. Reihe A, Pflanzenzuchtung, 19: 229229.

Charrier, A., 1984. Genetic Resources of the Genus Abelmoschus Med. (Okra). 1st Edn., Internat. Board for Plant Genetic Resources, Rome, pp: 61.

Chizaki, Y., 1934. Another new haploid plant in Triticum monococcum L. Bot. Mag. Tokyo, 48: 621-628.

Clarindo, W.T., C.R. Carvalho and M.A. Mendonca, 2012. Cytogentic flow cytometry data expand knowledge of genome evolution in three Coffea species. Plant Syst. Evol., 298: 835-844. DOI: 10.1007/s00606-012-0595-7

Datta, P.C. and A. Naug, 1968. A few strains of Abelmoschus esculentus (L.) Moench their karyological in relation to phylogeny and organ development. Beitr. Biol. Pflanzen.

Dolezel, J., J. Bartos, H. Voglmayr and J. Greilhuber, 2003. Nuclear DNA content and genome size of trout and human. Cytometry Part A, 51A: 127-128. PMID: 12541287

Duzyaman, E. and H. Vural, 2003. Evaluation of pod characteristics and nutritive value of okra genetic resources. Acta Hort., 598: 103-110.

Duzyaman, E., 1997. Okra: Botany and Horticulture. In: Horticultural Review, Janick, J. (Ed.), John Wiley and Sons, Inc., pp: 41-72.

Fletcher, D.M., M.B. Vogt, H.E. Pirner, A.M. Hess and R.A. Bowen et al., 2013. Flow cytometry baseline on peripheral leukocyte cell profiles for dairy goat kids. Am. J. Anim. Vet. Sci., 8: 177-189. DOI: 10.3844/ajavsp.2013.177.189

Ford, L.R., 1938. Fractions. Am. Math. Monthly, 45: 586-601.

Gadwal, V.R., A.B. Joshiand R.D. Iyer, 1968. Interspecific hybrids in Abelmoschus through ovule and embryo culture. Indian J. Genetics Plant Breed., 28: 269-274.

Greilhuber, J., 1998. Intraspecific variation in genome size: A critical reassessment. Ann. Bot., 82: 27-35.

Hamon, S. and D.H. Van Sloten, 1998. Characterization and evaluation of okra. Plant Genetic Resour.

Hanson, L., K.A. McMahon, M.A.T. Johnson and M.D. Bennett, 2001. First nuclear DNA c-values for 25 angiosperm families. Ann. Bot., 87: 251-258. DOI: 10.1006/anbo. 2000.1325

Iannelli, D., C. Cottone, M. Viscardi, L. D'Apice and R. Capparelli et al., 1998. Identification of genotypes of lemon by flow cytometry and RAPD markers. Int. J. Plant. Sci., 159: 864-869. DOI: 10.1086/297608 
Kamalova, G.V., 1977. Cytological studies of some species of the Malvaceae. Uzbekistan Biologija Zurnali.

Kovarova, P., A. Navratilova, J. Macas and J. Dolezel, 2007. Chromosome analysis and sorting in Vicia faba using flow cytometry. Biol. Plantarum, 51: 433-48. DOI: 10.1007/s10535-007-0009-9

Kron, P., J. Suda and B.C. Husband, 2007. Applications of flow cytometry to evolutionary and population biology. Annu. Rev. Ecol. Syst., 38: 847-876.

Kuwada, H., 1966. The new amphidiploid plant named Abelmoschus tubercular esculentus, obtained from the progeny of the reciprocal crossing between A. tuberculatus and A. esculentus. Jap. J. Breed, 16: 21-30.

Kuwada, S., 1961. Masuda, T. and Asai, M. Chem. Pharm. Bull.

Lema-Ruminska, J., 2011. Flow cytometric analysis of somatic embryos, shoots and calli of the cactus Copiapoa tenuissima Ritt. Form monstriusa. Plant Cell Tissue Organ. Cult., 106: 531-535. DOI: 10.1007/s11240-011-9941-7

Lucretti, S., L. Nardi, P.T. Nisini, F. Moretti and G. Gualberti et al., 1999. Bivariate flow cytometry DNA/BrdUrd analysis of plant cell cycle. Methods Cell Sci., 21: 155-166. DOI: 10.1023/A:1009893008892

Mahadeen, A.Y., 2014. Effect of polyethylene black plastic mulch on growth and yield of two summer vegetable crops under rain-fed conditions under semi-arid region conditions. Am. J. Agric. Biol. Sci., 9: 202-207. DOI: 10.3844/ajabssp.2014.202.207

Marhold, K., H. Kudoh, J.H. Pak, K. Watanabe and S. Spaniel et al., 2010. Cytotype diversity and genome size variation in eastern Asian polyploidy Cardamine (Brassicaceae) species. Ann. Bot., 105: 249-264. DOI: 10.1093/aob/mcp282

Medvedeva, I., 1936. Rannii Baratynskii.

Nakagawa, M., T. Ohkawa and Y. Kaneko, 2013. Flow cytometric assessment of cytotype distributions within local populations of Phragmites australis (Poaceae) around Lake Biwa, the largest lake in Japan. Plant Species Biol., 28: 94-100. DOI: 10.1111/j.1442-1984.2012.00370.x

Negron-Ortiz, V., 2007. Chromosome numbers, nuclear DNA content and polyploidy in Consola (cactaceae) and endemic cactus of the Caribbean Island. Am. J. Bot., 94: 1360-1370. DOI: 10.3732/ajb.94.8.1360

Nora, S., S. Castro, J. Loureiro, A.C. Goncalves and H. Oliveira et al., 2013. Flow cytometic and karyological analyses of Calendula species from Iberian Peninsula. Plant Syst. Evol., 299: 853-864. DOI: $10.1007 / \mathrm{s} 00606-013-0767-0$
O'Brien, I.E.W., D.R. Smith, R.C. Gardner and B.G. Murray, 1996. Flow cytometric determination of genome size in Pinus. Plant Sci., 115: 991-999. DOI: 10.1016/0168-9452(96)04356-7

Ochatt, S.J., C. Conreux and L. Jacas, 2013. Flow cytometry distinction between species and between landraces within Lathyrus species and assessment of true-to-typeness of in vitro regenerants. Plant Syst. Evol., 299: 75-85. DOI: 10.1007/s00606-012-0704-7

Omonhinmin, C.O. and M.E. Osawaru, 1991. Morphological Characterization of Two Species of Abelmoschus: Abelmoschus esculentus and Abelmoschus caillei. Plant Genetic Resou. Newsletter, 144: 51-55.

Palomino, G., J. Dolezel, I. Méndez and A. Rubluo, 2003. Nuclear genome size analysis of Agave tequilanaWeber. Caryologia, 56: 37-46. DOI: 10.1080/00087114.2003.10589305

Purewal, S.S. and G.E. Randhawa, 1947. Studies in Hibiscus esculentus (Ladyfinger) (Okra) I. Chromosome and pollen studies. Indian J. Agric. Sci.

Rayburn, A.L. and J.A. Auger, 1990. Genome size variation in Zea mays ssp. mays adapted to different altitudes. Theor Applic. Genet., 79: 470-474. DOI: 10.1007/BF00226155

Roux, N., A. Toloza, Z. Radeck, F.J. Zapata-Arias and J. Dolezel, 2003. Rapid detection of aneuploidy in Musa using flow cytometry. Plant Cell Rep., 21: 483-490. DOI: 10.1007/s00299-002-0512-6

Roy, R.P. and R.P. Jha, 1958. A semi-asynaptic plant of Abelmoschus esculentus (L.) Moench.(= Hibiscus esculentus L.). Cytologia, 23: 356-361.

Salameh, N. and M. Kasrawi, 2007. Inheritance of Fruit Length, Diameter and Number of Fruit Ridges in Okra (Abelmoschus esculentus L.) Landraces of Jordan. Jordan J. Agric. Sci., 3: 439-452.

Salameh, N. and M. Kasrawi, 2011. Inheritance of Fruit, Petiole and Stem color in different crosses in Okra (Abelmoschus esculentus L.) Landraces of Jordan. Mutah Natural Applied Sci., 26: 43-62.

Siemonsma, J.S., 1981. A survey of indigenous vegetables in Ivory Coast. Proceedings of the 6th African Symposium on Horticultural Crops, (HC' 81), Ibadan, Nigeria.

Skovsted, A., 1935. Cytological Studies in Cotton: III. A Hybrid Between Gossypium Davidsonii Kell and G. Sturtii F. Muell. 
Suda, J., P. Kron, B.C. Husband and P. Travnicrk, 2007. Flow Cytometry and Ploidy: Applications in Plant Systematics, Ecology and Evolutionary Biology. In: Flow Cytometry with Plant Cells: Analysis of Genes, Chromosomes and Genomes, Dolezel, J., J. Greilhuber and J. Suda (Eds.), John Wiley and Sons, Weinheim, ISBN-10: 3527610936, pp: 103130.

Tavares, A.C., J. Loureiro, C. Cavaleiro, L. Salgueiro and J.M. Canhoto et al., 2013. Characterization and distinction of two subspecies of Eryngium duriaei J. Gay ex Boiss. and Iberian endemic Apiaceae, using flow cytometry and essential oils composition. Plant Syst. Evol., 299: 611-618. DOI: 10.1007/s00606012-0747-9

Temsch, E.M. and J. Greilhuber, 2000. Genome size variation in Arachis hypogaea and A. monticola reevaluated. Genome, 43: 449-451. DOI: 10.1139/gen43-3-449
Tischler, G., 1937. Die Halligenflora der Nordsee im Lichte cytologischer Forschung. Cytologia, 1: 162170.

Walker, D.J., I. Monino, E. Gonzalez, N. Frayssinet and E. Correal, 2005. Determination of ploidy and nuclear DNA content in populations of Atriplex halimus (chenopodiaceae). Botanical J. Linnean Society, 147: 441-448. DOI: 10.1111/j.10958339.2004.00379.x

Winkelmann, T., R.S. Sangwan and H.G. Schwenkel, 1998. Flow cytometric analyses in embryogenic and non-embryogenic callus line of Cyclamen persicum Mill: relation between ploidy level and competence for somatic embryogenesis. Plant Cell Rep., 17: 400-404. DOI: 10.1007/s002990050414 